John Carroll University

Carroll Collected

Sociology

2007

\title{
Testing theories of doctoral student persistence at a hispanic serving institution
}

Gloria S. Vaquera

John Carroll University, gvaquera@jcu.edu

Follow this and additional works at: https://collected.jcu.edu/soc-facpub

Part of the Sociology Commons

\section{Recommended Citation}

Vaquera, Gloria S., "Testing theories of doctoral student persistence at a hispanic serving institution" (2007). Sociology. 31.

https://collected.jcu.edu/soc-facpub/31

This Article is brought to you for free and open access by Carroll Collected. It has been accepted for inclusion in Sociology by an authorized administrator of Carroll Collected. For more information, please contact connell@jcu.edu. 


\title{
TESTING THEORIES OF DOCTORAL. STUDENT PERSISTENCE AT A HISPANIC SERVING INSTITUTION
}

\begin{abstract}
Little empirical work exists which tests theories of doctoral student persistence. Among these studies, there is limited representation of minority students. To counter this state of affairs, this study uses a sample of four doctoral cohorts enrolled at a Hispanic Serving Institution. Focusing on the earlier stages of graduate study, I adapt theories of persistence previously employed for undergraduate students (Hurtado, 1992; I lurtado \& Carter, 1997; Tinto, 1993). Testing the impact of student background characteristics, departmental context, and student social and academic integration on persistence, findings are mixed. Strongest support is found for the effect of academic integration, father's education, agc. and being Latina/o. Weak support is found for the effect of departmental characteristics, such as department racial climate.
\end{abstract}

\section{INTRODUCTION}

It is estimated that for the past 40 years, doctoral programs have cxperienced attrition rates of approximately $50 \%$ (Abedi \& Benkin, 1987; Bowen \& Rudenstinc, 1992: Lor itts, 2001). While the rates of attrition vary by discipline, department, and institution, this recorded level of attrition has been stable over many decades. Institutions of higher education have devoted much energy and time to enrollment management efforts at the undergraduate level; however, 
graduate attrition has been, for the most part. overlooked. Thus, doctoral student departure remains an invisible problem which researchers are recently attempting to understand.

Some may argue that a certain amount of attrition from doctoral programs is desirable because it results in producing only the most deserving graduates. However, the reality is that many qualified and able students leave. Studies indicate that the profile of a graduate student departer is not synonymous with the academically weak student (Abedi \& Benkin, 1987; Golde, 2005; Lovitts, 2001). In these studies, such indicators as GRE scores, or undergraduate grade point average, have not been good predictors of eventual graduation. The loss of talented individuals clearly impacts the disciplines, departments, and universities. Thus, the problem of doctoral student departure is costly not only to the individual, but to the institution.

Persistence, at the earlier stages of the doctoral program, for students enrolled at a Hispanic Serving Institution is the focus of this study. A doctoral student is defined as such based on their admission to a doctoral program at the University of New Mexico. A variety of disciplines (excluding professional programs as identified by the institution), such as biology, chemistry, history, sociology, English, and political science, are included. The sample consists of four cohorts of students who are mostly at the second stage of the doctoral program. Stage two is described as the development of competence and spans the time from the start of the second year through the completion of all requirements for a Ph.I). other than the dissertation itself (Bowen \& Rudenstine, 1992). Stage one is the first year in a doctoral program, and stage three is often referred to as $\triangle B D$ or the dissertation writing stage. Past studies on Ph.D. attrition have noted that the majority of doctoral attrition happens during stage one and stage two (Bowen \& Rudenstinc. 1992; Moore, 1985; Nerad \& Cerny, 1993).

Studies on doctoral student departure in general have lacked a sufficient sample of minority students, thus this study draws a sample of doctoral students from a Hispanic Serving Institution. By targeting a university known for its Ph.D. production of underrepresented groups, this study secks to also address the experiences of students of color, specifically Hispanics, within graduate education.

\section{LITERATURE REVIEW}

Little theoretical work addresses the issue of doctoral student persistence (or departure). However, at the undergraduate level, many studies have been conducted to consider the issue of voluntary student departure. Although clear differences exist between undergraduate and doctoral educational experiences, theories on undergraduate student attrition provide a foundation from which to consider doctoral level attrition. This review of the literature thus, begins with the examination of Vincent Tinto's theory of undergraduate student 
persistence (1975, 1987, 1988, 1993). Additional studies on undergraduate populations are also included which provide further theoretical grounding. To this theoretical framework, relevant studies on doctoral student persistence are connected, as well as work that specifically considers the experiences of Latino graduate students.

According to Tinto's (1975) theory, attrition is a longitudinal process that results from interactions between a student and his/her educational environment. The theory hypothesizes that persistence is a function of the match between an individual's motivation and academic ability and the institution's academic and social characteristics. Background characteristics, however, are critical in shaping an individual's motivation. Tinto contends that initially students' background characteristics influence commitment. The theory asserts that the match between an individual's characteristics and those of the institution form two underlying individual commitments: a commitment to completing college (total commitment) and a commitment to his or her respective institution (institutional commitment). This level of initial commitment then facilitates integration.

At the core of Tinto's theory is the concept of integration, derived from the work of Emile Durkheim who first described the importance of social integration or social cohesion to the functioning of society. For Tinto, integration into university life has two separate forms; social and academic integration. Social integration captures the involvement of a student into the social aspects of the university, such as membership in university clubs, sororities or fraternities, and peer group interactions. Academic integration describes the student's connection to the intellectual life of the institution. Typical ways to measure academic integration include accumulative grade point average, interaction with faculty members, or participation in academic activities.

Tinto's theory of student departure has been widely tested. Shortly after Tinto's (1975) first publication, Terenzini and Pascarella (1977) began efforts to operationalize key concepts of the model with undergraduate student populations. Comparing a population of "stayers" to "leavers," they found that students who persist reported higher levels of both social and academic integration. Continuing this research, Pascarella, Terenzini, and others have tested these concepts on single and multiple institution samples using a wide variety of background variables (Fox, 1986; Pascarella \& Chapman, 1983: Pascarella \& Tcrenzini, 1979. 1980; Stoccker, Pascarella. \& Wolfc, 1988: Terenzini, Lorang, \& Pascarella, 1981). Findings from these subsequent studics also confirm the impact of social and academic integration variables on students' departure decisions.

While the concepts of social and academic integration have been widely used on a variety of samples, there is considerable variability in the operationalization of these constructs. Researchers have tended to shape the measures of formal and informal interactions to reflect their own ideas of integration. In general, most studies on undergraduate departure have examined integration in terms of participation both in social and academic settings. Absent from most of 
these works is a psychological dimension of integration that captures subjects' feelings of identification and affiliation with a campus.

One exception is Hurtado and Carter (1997), who have examined the psychological sense of integration. Hurtado and Carter have added the concept of sense of helonging. This additional measure of integration is a subjective measure that attempts to capture an individual's perceptions about being a part of social group. Hurtado and Carter (1997) found that for Latino college students discussing coursework with other students outside of class and participation in social-community organizations were strongly related to a broader sense of group cohesion. Thus, sense of belonging may be an important mediating factor for integrating behaviors.

Most studies regarding doctoral level attrition do not specifically test Tinto's theory of student departure; however, all incorporated the concepts of integration in some form. Lovitts' (2001) study, more so than any of the others, directly connects the concepts of both social and academic integration to the doctoral student experience. Lovitts' study of 816 doctoral students, 511 of whom completed their degrees and 305 did not, enrolled at two universities, found that completers have a higher level of academic and social integration than students that decided to leave their doctoral program. She also found that academic integration is more important than social integration, which is understandable given the nature of graduate education. Golde's (2005) study, found further corroborating evidence that having a positive relationship with advisors has a significantly higher impact on persistence and graduation in the sciences, which are more apprentice oriented than the humanities. Abedi and Benkin (1987) also found differences in relationships with faculty within a sample of completers and non-completers. Thus, having strong faculty/student interaction, an indicator of academic integration, was also important in these two additional studies.

Various studies found that financial support was a positive factor in retention efforts, however, having a private fellowship that does not require interaction with faculty can become an obstacle for integration (Bowen \& Rudenstine, 1992; Lovitts, 2001; Solorzano, 1993). Research, graduate or teaching assistantships (typically department funded) provide a direct link with faculty, whereas private fellowships do not. Studies found that working with faculty members increased a student's integration and connection to the department (Bowen \& Rudenstine, 1992; Golde, 2005: Lovitts, 2001: Nerad \& Cerny, 1993). Having opportunitics for integration within a department through a research or teaching assistantship, that was not overly burdensome, had a positive impact on persistence (Golde, 2005; Nerad \& Cerny, 1993).

Another significant finding across the various studies is that doctoral level attrition is specific to the discipline and department (Abedi \& Benkin, 1987; Golde, 2005; Lovitts, 2001 ; Nerad \& Cerny, 1993). Graduation rates and average time-to-degree rates appear to be embedded in the discipline. High attrition is also correlated with longer time-to-degree (Bowen \& Rudenstine, 1992). In 
cxamining the differences in attrition and time-to-degree across disciplines, researchers have come to examine the nature of graduate training within departments. Departments that have a team oriented approach with close working relationships of doctoral students and faculty in research leading to a dissertation, finish more rapidly. Such apprentice models of graduate education arc more common in the sciences. Conversely, departments that encourage students to work independently, have higher rates of attrition. Departments within the humanities and social sciences have both high levels of attrition and longer time-to-degree.

Another consistent finding is that students who leave doctoral programs tend to leave during the earlier stages of doctoral education. Although doctoral study is less structured, as compared with undergraduate study, and varies greatly from department to department, there are three distinct stages common to doctoral program progress. The first is an introductory stage and involves taking of formal course-work. The second stage involves taking a general examination or qualifying exams and selecting a dissertation topic. The final stage, advancement to candidacy, is one of intensive dissertation research and writing (Bowen \& Rudenstine, 1992). The majority of doctoral student departure occurs prior to advancement to candidacy, during stage one or two (Abedi \& Benkin, 1987; Bowen \& Rudenstine, 1992; Golde, 2005; Lovitts, 2001).

Studies on doctoral student departure in general have lacked a sufficient sample of Hispanic students; however, various qualitative studies have examined the experience of Hispanics in higher education (Cuadraz, 1992. 1993: Gándara. 1982, 1993, 1995; Gonzalez, Marin, Figueroa, Moreno, \& Navia, 2002; Gonzalez, Marin, Perez, Figueroa, Morena, \& Navia, 2001; Ibarra, 1996, 2001; Solorzano, 1993). While these studies may not specifically address student departure, they do describe the experience of Latina/o graduate students. A common theme in these studies is a struggle to survive in academia, which has been, and continues to be, a White, male, dominated institution. Subjects relate their experiences of being made to feel like an outsider or simply not fitting in. Some studies discuss this tension as resulting from a kind of culture mismatch, lack of cultural capital, or simply differences between Latina/o students and the institution. Other studies indicate that the tension students experience is a result of a conservative. restrictive, and racist environment (Gonzalez et al., 2002). Thus, what is described is a less than friendly environment, whether overtly or discretely racist, in which doctoral education is provided.

These qualitative studies of doctoral students complement studies conducted at the undergraduate level that consider campus racial climate. Racial conflict has become frequent on college campuses (Feagin \& Vera, 1995; Loeb, 1994; Loo \& Rolison, 1986; Sidel, 1994). Sidel's (1994) study of 17 college campuses found that racial and ethnic minority students, women, and gay and lesbian students were made to feel like outsiders on their college campuses. Clearly, racial conflict or racial tension impacts the student body, faculty, and administration. However, 
while a university community may experience racial incidents or ethnoviolence, studies have found that student perceptions of college environments vary by race (Hurtado, 1992). Thus, students of color are more likely than their White counterparts to negatively evaluate the racial climate of a university or to report feelings of alienation.

Although many works have discussed obstacles that students of color face on college campuses, few studies have included measures of campus racial climate in models of student persistence (Hurtado \& Carter, 1997; Tracey \& Sedlacek, 1987). Using data from the National Survey of Hispanic Students (NSHS), a national longitudinal study of Latino/a college students. Hurtado and Carter (1997) found that campus racial climate (measured as perceptions of hostility) had a negative direct effect on sense of belonging. Latino/a students were less likely to feel a part of the campus community if they perceived discrimination. Thus, a measure of campus racial climate is important to include in persistence studies.

\section{Current Study and Conceptual Framework}

The purpose of this study is to examine doctoral student persistence (or departure) during the earlier stages of the doctoral program. This work contributes to the broader topic of doctoral student persistence by empirically testing theories of persistence previously used on undergraduate populations (Hurtado, 1992; Hurtado et al., 1998; Hurtado \& Carter, 1997; Tinto, 1975, 1987, 1988, 1993). In hopes of addressing the sampling problems of other studies, this study uses a sample of doctoral students enrolled at a Research I-Hispanic Serving Institution to ensure inclusion of a substantial number of Latinas/os. By understanding the factors associated with doctoral student persistence in general, and Latinos specifically, departments may improve retention efforts and ultimately reduce attrition rates for all students.

All together, the literature suggests that doctoral student persistence is primarily a result of departmental characteristics and the opportunities for integrating experiences that are available to graduate students. At the heart of this theory are those integrating experiences that foster both social and academic integration. A doctoral student's sense of belonging is also important and grows out of integrating experiences within the department. Having a strong sense of belonging develops into an affiliation with the department and, most importantly, their future profession.

There are indications that the experiences of Latina/o doctoral students differ from that of White non-Hispanic students. Thus, race and ethnicity are also salient factors to consider. In light of studies of undergraduate student populations, as well as the qualitative studies on Latina/o graduate students, the concept of racial climate, applied to the department level, is also included (Cuadraz, 1992, 1993. Gándara, 1982, 1993, 1995; Gonzalez et al., 2001, 2002; Hurtado \& Carter, 1997; Ibarra, 1996, 2001; Solorzano, 1993). 
To understand doctoral student persistence in general, and also the experiences of students of color (in this study being Latinas/os), the following model is used (see Figure 1). As shown in the model, this study sceks to understand how background characteristics, departmental context, social integration, and academic integration impact doctoral student persistence. In order to test these theoretical concepts, a survey measuring the identificd theoretical concepts is used. The primary research question is, what factors contribute to graduate student persistence in earlier stages of the doctoral program? This study measures and tests the impact of the following theoretical constructs on persistence: background characteristics, departmental context, social integration, and academic integration.

\section{METHODOLOGY}

The survey instrument for this study was derived from previous studies of doctoral student persistence (Lovitts, 2001; Nerad \& Cerny, 1993; Solorzano, 1993), as well as surveys of undergraduate populations (Hurtado \& Carter, 1997; Hurtado et al., 1998; Pascarella \& Terenzini, 1980). Questions were selected based on how well they matched theoretical constructs. The survey was designed to capture background characteristics of doctoral students as well as experiences within their graduate programs that were not adequately addressed in previous work.

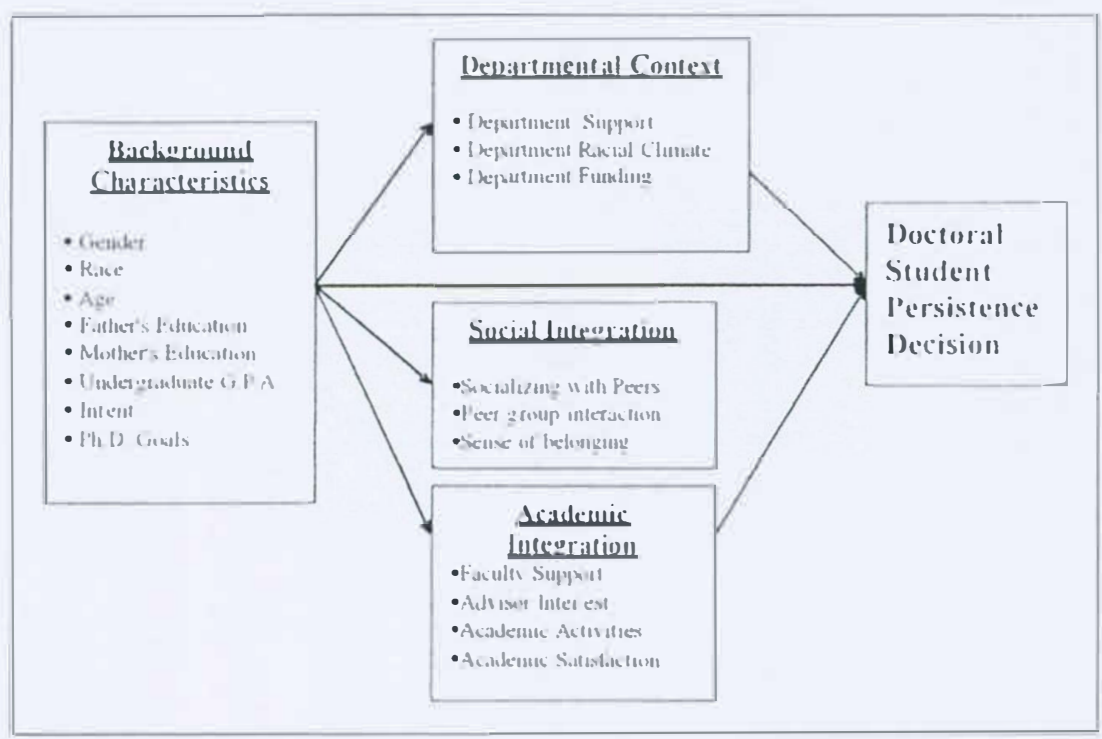

Figure 1. Theoretical model of doctoral student persistence. 
In order to consider the impact of various factors on doctoral student departure, a list of full-time students who enrolled in a doctoral program during the fall of 1996 through fall 1999 was gencrated. Four cohorts were selected so as to capture individuals past stage one and stage two, with some individuals at stage three and possibly graduated. The sample was further restricted to doctoral students who were U.S. citizens or permanent residents enrolled in doctoral programs. A total of 542 individuals were identified with an average of 135 individuals per cohort. Included were doctoral students from the Colleges of Arts \& Sciences, Education, Enginecring, and Fine Arts. Out of this sample, 315 surveys were returned, with 295 uscable surveys ( $54 \%$ of the sample). A comparison of study subjects to the full sample found that the respondents had similar demographic characteristics.

The dependent variable for this study, persistence, has a 3-point ordinal scale that differentiates the various stages of student departure. The three categories in the dependent variable arc: (1) departer (left), (2) at-risk of leaving (thought of leaving but still enrolled), and (3) persister (those who had never thought of leaving). This variable acknowledges the process model of Ph. I). program attrition. Out of the 295 returned and uscable surveys, 54 individuals had graduated by the time they received the survey. For these individuals, the survey items were slightly re-phrased to read "did you ever consider leaving the University of New Mexico without finishing your Ph.D.?" The response options remained the same, with the at-risk category asking if they had ever thought of leaving the doctoral program without finishing. Of the 54 graduates that responded to the survey, $70 \%$ had never thought of leaving, and $30 \%$ had thought of leaving. but had graduated.

The independent variables in this study are grouped under the following constructs: background characteristics, departmental context, social integration, and academic integration. The analysis used in this study utilizes both nominal and continuous variables, as well as a number of scales. Principal components analysis was used as a method to reduce many individual survey items into usable constructs. Cronbach's alpha reliability scores were then used to test the reliability of the created scales (constructs). Because of the exploratory nature of this study I use a more lenient cutoff of 60 . Table 1 defines all the independent variables and scales used in this study. Table 2 provides the frequencies and descriptive statistics for each variable.

Ordinal logistic regrêssion (OLR), also referred to as the proportional odds model, is used to test the various theoretical constructs on doctoral student persistence. This model estimates the effects of independent variables on the log odds of having lower rather than higher scores on the dependent variable. The model is described by this probability model:

$$
\ln \left(\frac{P(Y \leq j)}{P(Y>j)}\right)=\alpha_{j}-\sum_{k=1}^{K} \beta_{k} X_{k}
$$


In the equation, $\alpha_{j}$ are intercepts indicating the logodds of lower rather than higher scores when all independent variables equal zero. Unlike multinomial logistic regression, OLR provides only one set of coefficients for each independent variable and thus, there is an assumption of parallel regressions. A positive coefficient indicates an increased chance that a subject with a higher score on the independent variable will be observed in higher categories.

\section{RESULTS}

Four nested models were used to consider the impact of various independent variables on the dependent variable. Model I includes background characteristics as control variables. Model II adds variables pertaining to departmental context. Model III adds social integration variables and lastly, model IV includes academic integration variables. The results of the ordinal logistic regression are provided in Table 3. Variables that were significant at the .10 level and below are indicated in this analysis. While traditionally a .05 cutoff for significance is most often used, a more liberal cutoff may be beneficial in further refining this model. The models were compared against one another using the likelihood ratio test, as well as a pseudo test for variance, Nagelkerke statistic.

In model I, two of the background characteristic variables had significant effects on doctoral student departure, age and father's education. Older students (age, $\beta=.038^{* *}$ ) were more likely to be in the higher category of persister: In regards to father's education, this nominal variable uses advanced or graduate degree as the reference category with two dummy variables included in the model. father having a high school education or less and father having some college experience to a $B A$ or equivalent. Father's having some college experience to a $B A$ degree $\left(\beta=.81^{* *}\right)$ had a negative impact on the probability of being in a higher category when compared with having a father with an advanced degree.

In model II, departmental context variables, age and father's education (some college $10 B A$ ) are still significant. Additionally, one of the racial and ethnic categories is also marginally significant (at the .10 level). The racial and ethnic categories used White as the reference category with two dummy variables, Hispanic and other minority. Being Hispanic $\left(\beta=.678^{\dagger}\right)$, makes one more likely to be in the persister category than being White. Additionally, two of the three departmental context variables are also significant. Evaluating one's doctoral department as supportive $\left(\beta=.06 I^{*}\right)$, had a positive effect on the probability of being in the persister category. Department racial climate was also significant $\left(\beta=-.114^{*}\right)$, indicating that the more negative the racial climate within the department the less likely a student would be in the persister category.

In model III, social integration, being Hispanic, father's education (some college to $B A$ ), and age are all still significant, as well as department racial climate. The addition of three social integration variables finds that only one is marginally significant, social integration with peers $\left(\beta=.\left(048^{\dagger}\right)\right.$. Thus, if a student 
Table 1. Independent Variance Definitions

\author{
Background Variables \\ Gender \\ A nominal variable indicating the gender (male or female) of \\ each student. Dummy variables are used with female as the \\ reference category. \\ Race \\ A nominal variable indicating the race/ethnic background \\ (Hispanic, Other Minority, and White) of the student. \\ Dummy variables are used with White as the reference \\ category. \\ Age \\ An interval variable given in years. \\ Father's education \\ An ordinal variable indicating father's level of education \\ (HS or less, some college to BA, graduate degree). Dummy \\ variables are used with graduate degrees as the reference \\ category. \\ Mother's education \\ An ordinal variable indicating mother's level of education \\ (HS or less, some college to BA, graduate degree). Dummy \\ variables are used with graduate degrees as the reference \\ category. \\ Undergraduate GPA \\ A nominal variable indicating the cumulative undergraduate \\ grade point average (A's or mostly all A's, or mostly B's or \\ less). Dummy variables are used with mostly $B$ 's or less as \\ the reference category. \\ Intent \\ A nominal variable indicating the degrees intent (Ph.D. or M.A. \\ or Not sure). Dummy variables are used with MA or not sure as \\ the reference category. \\ Ph.D. goals \\ An interval 7-item scale measuring importance of various \\ items in obtaining a Ph.D. $(5=$ very important to $1=$ not \\ very important). (1) desire for higher salary; (2) desire for \\ the status and prestige of having a Ph.D.; (3) control \\ over work schedule; (4) encouraged by faculty; (5) job \\ prospects were not good; (6) encourage by family \\ (7) desire to give back to community. Alpha reliability for \\ this scale is .61 .

\section{Departmental Context} \\ Department support \\ An interval 5-point continuum scale asking respondents to \\ characterize departmental support: (1) research mode- \\ teamwork oriented or individualistic; (2) faculty relations- \\ unified faculty or factions among faculty; (3) faculty perceptions \\ of graduate students-treated as jr. faculty or adolescents; \\ (4)financial support for grad students-many or few sources; \\ (5) program climate - friendly or competitive. Alpha reliability \\ for this scale is .74 .
}


Table 1. (Cont'd.)

Department racial climate

Department funding

\section{Social Integration} Socializing with peers

Peer group interaction

Sense of belonging

\section{Academic Integration}

Faculty support
An interval 4-item scale asking respondents to agree or disagree with a series of statements: (1) climate of department is nonracist; (2) department emphasizes importance of diversity; (3) there is a need for more diversity in department (reversed for analysis); (4) department actively recruits faculty from under-represented groups. Alpha reliability for this scale is .76 .

A nominal variable indicating if the majority of their doctoral education funding came from a departmental source (GA, TA, $T A$, or PA being primary source of funding or other sources of primary funding). Dummy variables are used with other source of primary funding being the reference category.

An interval 2-item scale asking respondents how often $(5=$ often to $1=$ never) they: (1) socialize on campus with fellow graduate students; (2) socialize off campus with fellow graduate students. Alpha reliability for this scale is .78 .

An interval 6-item scale asking respondents if they agreed strongly (5) to disagreed strongly (1) to the following statements: (1) developed close personal relationships with other graduate students; (2) developed personally satisfying friendships with other students; (3) grad student relationships have positive influence on personal growth; (4) grad student relationships have positive influence on intellectual growth; (5) difficulty making friends with other graduate students (reverse coded); (6) have supportive graduate students to listen to personal problems (reverse coded). Alpha reliability for this scale is .90 .

An interval 3-item scale asking respondents if they agreed strongly (5) to disagreed strongly (1) to the following statements (1) there were faculty role models within department; (2) feeling included in departmental activities; (3) feeling a sense of community with others in department. Alpha reliability for this scale is .88 .

An interval 6-item scale asking respondents if they agreed strongly (5) to disagreed strongly (1) to the following statements: (1) faculty members are good teachers; (2) there is a lot of contact between professors and graduate students; ( 3 faculty are sensitive to graduate student interests, needs, and aspirations; (4) faculty members have a strong impact on intellectual development; (5) Faculty go out of their way to help students remain in the program; (6) easy to develop close friendships with faculty members in my department. Alpha reliability for this scale is .87 . 
Table 1. (Cont'd.)

\begin{tabular}{|c|c|}
\hline Advisor interest & $\begin{array}{l}\text { An interval } 3 \text {-item scale asking respondents about their advisor's } \\
\text { interest }(5=\text { A lot to } 1=\text { Not at all): (1) you as a person; (2) your } \\
\text { ideas; (3) your professional development. Alpha reliability for this } \\
\text { scale is } .88 \text {. }\end{array}$ \\
\hline Academic activities & $\begin{array}{l}\text { An interval 5-item scale asking the frequency of participation } \\
\text { ( } 5=\text { A lot to } 1=\text { Not at all), in: (1) colloquia/brown bag lunches; } \\
\text { (2) departmental committees; ( } 3 \text { ) graduate student government } \\
\text { activities: (4) departmental graduate student organizations; } \\
\text { (5) academic conferences. Alpha reliability for this scale is } .75 \text {. }\end{array}$ \\
\hline $\begin{array}{l}\text { Academic } \\
\text { satisfaction }\end{array}$ & $\begin{array}{l}\text { An interval 3-item scale asking the respondent if they agreed } \\
\text { strongly (5) to disagreed strongly (1) to the following statements: } \\
\text { (1) satisfied to the extent of intellectual development; } \\
\text { (2) doctoral program experience has had positive influence on } \\
\text { intellectual growth; (3) satisfied with the academic experience } \\
\text { in doctoral program. Alpha reliability for this scale is .91. }\end{array}$ \\
\hline
\end{tabular}

reports a higher level of social integration with peers he or she is more likely to be in the persister category.

In the final model, academic integration, four variables are added. The effect of being Hispanic (now $\beta=.905^{*}$ ), father's education (some college $10 \mathrm{BA}$ ), age, and mother's education (some college to $B A$ ) are all significant. Three of the new variables arc also significant, academic satisfaction, academic activitics, and advisor interest. The more satisfaction a student reports with his or her academic experience $\left(\beta=.247^{* * *}\right)$, the more likely he or she is to be in the persister category. Similarly, the more academic activities the student participates in $\left(\beta=.048^{\dagger}\right)$, the more likely he or she is to persist. Having an advisor who shows interest in him or her $\left(\beta=.137^{* *}\right)$, also makes a student more likely to persist.

In comparing the models to each other, -2log likelihood statistic is used. Overall, the model improves with each addition of new variables, at the .02 level to the .001 level. In ordinal logistic regression there is no $R^{2}$ equivalent identifying the variance explained by this model. However, a Nagelkerke statistic is an approximation of the variance explained. Model IV shows a .325 , or nearly $33 \%$ of the variance explained. Indicating, like the log likelihood test comparison, that model IV is the best model for doctoral stage one and stage two persistence.

To better understand the impact of the significant variables on the dependent variable, doctoral student persistence, predicted probabilities were calculated (see Table 4). Holding every other independent variable at its mean, we can calculate the probability of being in each of the three dependent variable categories by changing the score or the measure of the independent variables in the final model. In this study, being Hispanic had a positive impact on being in the category of 
persister $(69 \%)$ and was higher than White students' probabilities $(51.41 \%)$. For parental education, having a father with some college experience to a BA (or equivalent), had a negative impact on the probability of being in the persister category $(40.85 \%)$. Having a father with a high school or less level of education or an advanced degree, had a higher probability of being in the persister category, $61.67 \%$. For the variables age, academic satisfaction, and advisor interest, scores are reported based around the mean plus or minus the standard deviation showing where the majority of the sample fell on these variables. Older students (age 48) were more likely to be in the persister category, $62.39 \%$, as compared with younger students (age 29), 47.46\%. Having a high degrec of academic satisfaction (range was 3 to 15), made a big impact persistence. Students reporting the highest level of academic satisfaction were $73.5 \%$ more likely to be in the persister category, as compared with those one standard deviation below the mean, who were at $34.83 \%$. For advisor interest, a similar pattern was found. Students reporting the highest level of advisor interest (range was from 0 to 15) were $64.65 \%$ more likely to be in the persister category, as compared with those one standard deviation below the mean, score of 8.2 , who were at $43.41 \%$.

\section{DISCUSSION}

The results of the model testing of doctoral student persistence in the earlier stages of the Ph.D. program are mixed. While retention theories suggest that input variables such as gender, academic background, intent, and having high aspirations for obtaining a Ph.D. (Ph.D. goals) are important factors, this study did not find corroboration. However, the scale used to measure Ph.D. goals has the lowest alpha reliability score (.61). Perhaps with further refinement we will find that this variable has a bigger impact on persistence. Support was found for parental level of education, more so father's than mother's, however, not in the manner that was expected. Given past research, having a father with an advanced degree (reported by $38 \%$ of the sample) typically has a positive and significant impact on persistence. In contrast, I found no difference between the most educated and the least educated within this sample. Furthermore, having a father with college experience to a $\mathrm{B} A$ (or equivalent) had a negative impact on persistence. It may be the case that those with the least and the most education are equally as encouraging of their children to pursue an advanced degrec, one group because the parents did not have those opportunities and the other group because they did. Age was also significant in an unexpected way, older students were more likely to persist than were younger students. The mean age in the sample was 38.2 , with a range of 25 to 66 .

The race variable was another background characteristic that proved to be significant. Within this sample, being Hispanic had a positive impact on persistence. This finding is contrary to all other past research that documents Hispanic educational attainment as being substantially lower than White students (Llagas, 
Table 2. Frequencies and Descriptive Statistics

\begin{tabular}{|c|c|c|c|c|c|c|c|}
\hline Variables & Frequency & Percent & Mean & Std. Dev. & Range & Mınimum & Maximum \\
\hline \multicolumn{8}{|l|}{ Dependent Variable } \\
\hline Departer-Thought of leaving and left $=1$ & 44 & $15 \%$ & 2.325 & 0.721 & & & 3 \\
\hline At-risk Think of leaving, but still enrolled $=2$ & 111 & $38 \%$ & & & & & \\
\hline Persister-Never thought of leaving $=3$ & 140 & $47 \%$ & & & & & \\
\hline \multicolumn{8}{|l|}{ Background Characteristics } \\
\hline \multicolumn{8}{|l|}{ Gender } \\
\hline Male $=1$ & 126 & $43 \%$ & 0.573 & 0.496 & & 0 & \\
\hline Female $=0$ & 169 & $57 \%$ & & & & & \\
\hline \multicolumn{8}{|l|}{ Race } \\
\hline Hispanic Latina/o & 32 & $11 \%$ & 2.708 & 0.652 & & 0 & \\
\hline Other minority & 22 & $7 \%$ & & & & 0 & \\
\hline White & 241 & $82 \%$ & & & & & \\
\hline Age & & & 38.44 & 9.243 & 41 & 25 & 66 \\
\hline \multicolumn{8}{|l|}{ Father's education } \\
\hline High school or less & 86 & $29 \%$ & & & & 0 & \\
\hline Some college to BA (or equivalent) & 96 & $33 \%$ & 2.092 & 0.818 & & 0 & \\
\hline Advanced degree & 113 & $38 \%$ & & & & & \\
\hline \multicolumn{8}{|l|}{ Mother's education } \\
\hline High school or less & 92 & $31 \%$ & & & & 0 & \\
\hline Some college to BA (or equivalent) & 137 & $46 \%$ & 1.908 & 0.726 & & 0 & \\
\hline Advanced degree & 65 & $22 \%$ & & & & & \\
\hline
\end{tabular}


Undergraduate GPA

Mostly A's = 1

Mostly B's or less $=0$

Intent

Ph.D. intent $=1$

M.A. / Not sure $=0$

Ph.D. goals

$\begin{array}{rl}164 & 56 \\ 131 & 44 \% \\ 243 & 82 \% \\ 52 & 18 \%\end{array}$

Departmental Context

Department support

Department racial climate

Department funding

Primarily funded by dept. $=1$

Primarily not funded by dept. $=0$

\section{Social Integration}

Socializing with peers

Peer group interaction

Sense of belonging

6.21

22.95

10.35

2.431

6.379

3.293

8

24
12

20.4

5.513

12.05

12.69

3.400

5.201

3.324

Academic satisfaction 
Table 3. Ordinal Logistic Regression Estimates $(N=295)$

(Standard Errors in Parentheses)

Ordinal Dependent Variable: $1=$ Departer; 2 = At-Risk; 3 = Persister

\begin{tabular}{|c|c|c|c|c|}
\hline Independent variables & $\begin{array}{l}\text { 1. Background } \\
\text { characteristics }\end{array}$ & $\begin{array}{l}\text { 2. Departmental } \\
\text { context }\end{array}$ & $\begin{array}{l}\text { 3. Social } \\
\text { integration }\end{array}$ & $\begin{array}{l}\text { 4. Academic } \\
\text { integration }\end{array}$ \\
\hline RACE - Hispanic & $\begin{array}{c}0.369 \\
(0.389)\end{array}$ & $\begin{array}{r}0.678^{\dagger} \\
(0.406)\end{array}$ & $\begin{array}{r}0.712^{\dagger} \\
(0.411)\end{array}$ & $\begin{array}{l}0.905^{*} \\
(0.427)\end{array}$ \\
\hline RACE - Other minority & $\begin{array}{l}-0.006 \\
(0.433)\end{array}$ & $\begin{array}{c}0.392 \\
(0.456)\end{array}$ & $\begin{array}{c}0.581 \\
(0.471)\end{array}$ & $\begin{array}{c}0.649 \\
(0.497)\end{array}$ \\
\hline Gender - Male & $\begin{array}{c}0.390 \\
(0.237)\end{array}$ & $\begin{array}{c}0.252 \\
(0.242)\end{array}$ & $\begin{array}{l}0.303 \\
(0.246)\end{array}$ & $\begin{array}{l}0.337 \\
(0.256)\end{array}$ \\
\hline $\begin{array}{l}\text { Undergraduate GPA - } \\
\text { Mostly A's }\end{array}$ & $\begin{array}{c}0.135 \\
(0.230)\end{array}$ & $\begin{array}{c}0.142 \\
(0.235)\end{array}$ & $\begin{array}{l}0.034 \\
(0.239)\end{array}$ & $\begin{array}{c}0.211 \\
(0.250)\end{array}$ \\
\hline $\begin{array}{l}\text { Father's education - } \\
\text { HS or less }\end{array}$ & $\begin{array}{l}-0.081 \\
(0.334)\end{array}$ & $\begin{array}{l}-0.066 \\
(0.340)\end{array}$ & $\begin{array}{l}-0.045 \\
(0.343)\end{array}$ & $\begin{array}{l}-0.088 \\
(0.356)\end{array}$ \\
\hline $\begin{array}{l}\text { Father's education - } \\
\text { Some college to BA }\end{array}$ & $\begin{array}{l}-0.811^{\star \star} \\
(0.291)\end{array}$ & $\begin{array}{l}-0.826^{\star \star} \\
(0.297)\end{array}$ & $\begin{array}{l}-0.777^{\star \star} \\
(0.300)\end{array}$ & $\begin{array}{l}-0.846^{\star \star} \\
(0.314)\end{array}$ \\
\hline $\begin{array}{l}\text { Mother's education - } \\
\text { HS or less }\end{array}$ & $\begin{array}{c}0.291 \\
(0.369)\end{array}$ & $\begin{array}{c}0.425 \\
(0.376)\end{array}$ & $\begin{array}{c}0.376 \\
(0.384)\end{array}$ & $\begin{array}{c}0.519 \\
(0.396)\end{array}$ \\
\hline $\begin{array}{l}\text { Mother's education - } \\
\text { Some college to BA }\end{array}$ & $\begin{array}{l}0.314 \\
(0.305)\end{array}$ & $\begin{array}{c}0.442 \\
(0.312)\end{array}$ & $\begin{array}{l}0.397 \\
(0.315)\end{array}$ & $\begin{array}{c}0.633^{\dagger} \\
(0.328)\end{array}$ \\
\hline Intent - Ph.D. & $\begin{array}{c}0.072 \\
(0.310)\end{array}$ & $\begin{array}{c}0.127 \\
(0.316)\end{array}$ & $\begin{array}{l}0.083 \\
(0.319)\end{array}$ & $\begin{array}{c}0.067 \\
(0.336)\end{array}$ \\
\hline Ph.D. goals & $\begin{array}{l}-0.012 \\
(0.022)\end{array}$ & $\begin{array}{l}-0.015 \\
(0.022)\end{array}$ & $\begin{array}{l}-0.020 \\
(0.023)\end{array}$ & $\begin{array}{l}-0.030 \\
(0.024)\end{array}$ \\
\hline Age & $\begin{array}{l}0.038^{\star \star} \\
(0.013)\end{array}$ & $\begin{array}{l}0.031^{*} \\
(0.014)\end{array}$ & $\begin{array}{c}0.036^{\star} \\
(0.015)\end{array}$ & $\begin{array}{c}0.032^{\star} \\
(0.016)\end{array}$ \\
\hline $\begin{array}{l}\text { GA/TA/RA Primary } \\
\text { financing of Ph.D. }\end{array}$ & & $\begin{array}{c}0.016 \\
(0.246)\end{array}$ & $\begin{array}{c}0.039 \\
(0.249)\end{array}$ & $\begin{array}{c}0.145 \\
(0.261)\end{array}$ \\
\hline Department support & & $\begin{array}{l}0.061^{*} \\
(0.029)\end{array}$ & $\begin{array}{c}0.013 \\
(0.037)\end{array}$ & $\begin{array}{l}0.000 \\
(0.041)\end{array}$ \\
\hline $\begin{array}{l}\text { Department racial } \\
\text { climate }\end{array}$ & & $\begin{array}{l}-0.114^{\star \star} \\
(0.00)\end{array}$ & $\begin{array}{c}-0.098^{\star} \\
(0.043)\end{array}$ & $\begin{array}{l}-0.062 \\
(0.046)\end{array}$ \\
\hline Socializing with peers & & & $\begin{array}{l}0.001 \\
(0.066)\end{array}$ & $\begin{array}{c}0.026 \\
(0.069)\end{array}$ \\
\hline Sense of belonging & & & $\begin{array}{c}0.068 \\
(0.057)\end{array}$ & $\begin{array}{l}-0.030 \\
(0.065)\end{array}$ \\
\hline Peer group interaction & & & $\begin{array}{r}0.048^{\dagger} \\
(0.025)\end{array}$ & $\begin{array}{c}0.016 \\
(0.026)\end{array}$ \\
\hline Academic satisfaction & & & & $\begin{array}{l}0.247^{\star \star \star} \\
(0.056)\end{array}$ \\
\hline Academic activities & & & & $\begin{array}{c}0.048^{\dagger} \\
(0.027)\end{array}$ \\
\hline Faculty support & & & & $\begin{array}{l}-0.048 \\
(0.038)\end{array}$ \\
\hline
\end{tabular}


Table 3. (Cont'd)

\begin{tabular}{lcccc}
\hline Independent variables & $\begin{array}{c}\text { 1. Background } \\
\text { characteristics }\end{array}$ & $\begin{array}{c}\text { 2. Departmental } \\
\text { context }\end{array}$ & $\begin{array}{c}\text { 3. Social } \\
\text { integration }\end{array}$ & $\begin{array}{c}\text { 4. Academic } \\
\text { integration }\end{array}$ \\
\hline Advisor interest & & & & $\begin{array}{c}0.137^{\star \star} \\
(0.044)\end{array}$ \\
Threshold - Leave $=1$ & -0.342 & -0.926 & 0.344 & $2.776^{\star}$ \\
Threshold - Leave $=2$ & $(0.786)$ & $(1.113)$ & $(1.224)$ & $(1.348)$ \\
-2log likelihood & $1.614^{\star}$ & 1.133 & $2.467^{\star}$ & $5.212^{\star \star \star}$ \\
Nagelkerke & $(0.789)$ & $(1.112)$ & $(1.233)$ & $(1.379)$ \\
\hline
\end{tabular}

${ }^{\dagger} p<.10 .{ }^{\star} p<.05 .{ }^{\star \star} p<.01 .{ }^{\star \star \star} p<.001$.

Table 4. Predicted Probabilities for Significant Variables

\begin{tabular}{llccc}
\hline Variable & Value & Departer & At-risk & Persister \\
\hline Race/Ethnicity & Hispanic & 3.25 & 24.46 & 69.04 \\
& Minority other & 4.15 & 28.97 & 66.88 \\
& White & 7.64 & 40.95 & 51.41 \\
& & & & \\
Level of father's education - & Yes & 11.25 & 47.9 & 40.85 \\
College experience to BA & No & 5.16 & 33.17 & 61.67 \\
Age & & & & \\
& 29 (younger) & 8.83 & 43.71 & 47.46 \\
Academic satisfaction & 48 (older) & 5.01 & 32.6 & 62.39 \\
& & & & \\
Advisor interest & 8.2 (low) & 14.02 & 51.5 & 34.83 \\
& 14.85 (high) & 3.06 & 23.44 & 73.5 \\
& & & & \\
& & & & \\
& & & & \\
& 15 (high) & 4.24 & 46.35 & 43.41 \\
& & 30.79 & 64.65 \\
\hline
\end{tabular}

2003; National Council of La Raza, 1998; Secada et al., 1998). This finding is likely an artifact of the institution type from which the sample is drawn. As a Hispanic Serving Institution, the University of New Mexico has particular advantages with regard to recruitment of both Latina/o faculty and staff. Latina/o faculty representation in 2003 was approximately 10\% (Office of Institutional Research [OIR], 2004), which is more than three times the national average, $3 \%$ (National Center for Education Statistics, 2004). While these numbers are better than the national average, they do not come close to being representative of the 
Hispanic population (42\%) of New Mexico (U.S. Census Bureau, 2006). On campus, there is a clear Hispanic presence with half of the undergraduate student population and $33 \%$ of all university staff being Hispanic. This ethnic presence is noticeable throughout the institution with the university supporting a number of ethnic centers (El Centro de la Raza), institutes (Southwest Hispanic Research Institute) and departments (Chicano Studies) that are geared for research pertaining to Latinas/os. Thus, all of these unique features of this institution create an environment in which Hispanic doctoral students are able to find support. Conversely, this data suggests that for White students and other minority students finding support is more challenging. Efforts should be taken to create a more supportive environment for all students, within their departments and the institution as a whole.

Among the departmental context variables, having department based funding as the primary source of funding for the Ph.D. did not have an impact on persistence in these earlier stages. Since some studies have suggested that this type of funding helps students become more engaged within their departments (Bowen \& Rudenstine, 1992, Golde, 2005; Solorzano, 1993), it was surprising that this was not significant. An assessment of the supportive nature of the department as a whole, department support, was found to be significant when only background characteristics and departmental context variables were modeled. Department racial climate showed stronger impacts on persistence in two of the models, but in the last was overshadowed by academic integration variables.

Only one of the social integration variables, social integration with pecrs, was moderately significant (at the .10 level). Socializing with peers and sense of belonging were not significant. While sense of belonging has been found to be a strong predictor of retention among undergraduates (Hurtado \& Carter, 1997), it did not have the same impact at this level. Thus, at the doctoral level, academic integration is far more important than social integration in determining persistence.

This study of doctoral student persistence has several limitations. As noted by Tinto's (1993) model, student departure and persistence happen over time. Thus, to study students' experiences in a doctoral program, a longitudinal cohort study would be preferred allowing the examination of various educational trajectories and outcomes. However, such a study is both costly and requires a full decade, or more, to determine completion rates. This study also focused on stage one and stage two persistence. The obvious limitation of this decision is that it fails to definitely provide a test as to the impact of particular theoretical concepts on completion. In using the four cohorts that were selected, many students, at the time of the survey, were three years to six years into their programs. Since time to degree varies from discipline to discipline, many individuals had not yet completed the dissertation. It is for that reason that this is a study of persistence during stage one and stage two and not a study of completion. However, strong assertions can be made about persistence in stage one and stage two and the probability of 
finishing. Lastly, having a single institution study limited the sample size and the range of doctoral institutions. Future inclusion of additional institutions would provide many more cases as well as possibly, sufficient numbers of African Americans and Asian Americans, to conduct additional comparisons among various racial and ethnic groups.

This study, though in many respects exploratory, does suggest some institutional and departmental changes that can improve doctoral education for all, and specifically underrepresented populations, such as Hispanics.

1. Improvements in Academic Environment. The impact of academic integration suggests a number of strategies that departments can take to improve the academic environment for all doctoral students. The analysis indicates that faculty support. especially that of an advisor, is important to doctoral student persistence. Thus, having the mentoring of an advisor is a critical ingredient in a student's success. Many believe the mentor/mentee or advisor/student relationship naturally develops on its own and that information, training, and skills are naturally passed on from mentor to mentec. However, the quality of mentoring varies from individual to individual, thus, departments could make efforts to ensure that knowledge is provided to the students through their mentors. Faculty and students alike may benefit from a formalized training addressing the various roles of both parties, expectations and support. Exposure to philosophics of mentoring and a discussion of student needs throughout the various stages of the doctoral program would assist newer faculty and even experienced faculty in providing better advising, mentoring, and guidance to graduate students.

Providing opportunities for students to develop intellectually would improve academic satisfaction. Departments should attempt to ensure that doctoral students engage intellectually. Intellectual development can be encouraged through seminars, brown bag lunches, or research groups organized around areas of shared interest. Additionally, research opportunities to work with faculty would go a long way toward helping students develop into junior colleagues. Such opportunities would facilitate the understanding of the research in a given ficld, in addition to acquiring the skills to conduct research, which are critical to creating independent researchers.

At the institutional level, faculty research support could be encouraged to incorporate graduate students into research projects. Thus, if institutionally funded projects give preference to projects that are directly linked to graduate student development, this will create more opportunities for educational growth of students and also contribute to the institution's commitment to doctoral students.

2. Increasing the Number of Minority Faculty and Staff. Increasing the number of faculty and staff of color would improve recruitment and retention efforts of underrepresented students, as well as the racial climate of institutions. As this study found, department racial climate showed some effect on persistence. While the Civil Rights movement and the Civil Rights Acts of 1964 and 1968, made an enormous impact on educational access for people of color, today academic 
departments remain predominately White. In 2003, White non-Hlispanic faculty comprised $80 \%$ of the instructional posts (NCES, 2004). Thus, diversifying the ranks of faculty would aid in improving departmental as well as campus racial climate. As theories on social distance (Bogardus, 1925) point out, having interactions with individuals that are different from yourself, helps to break down stereotypes and decreases discriminatory behavior. The anomaly of Hispanic students doing remarkably well in comparison to White students in this study, is a testament to the greater diversity of this Hispanic Serving Institution. The percentage of Hispanic doctoral students is matched by the percentage of Hispanic faculty. Beyond having access to faculty of color, the university provides the potential for supportive networks through various ethnic centers, research institutions, and cultural events. For predominately White institutions, this study suggests that creating a critical mass of minority presence within institutions may assist in retention efforts of doctoral students of color.

In conclusion, with some modifications, the experiences of doctoral students can improve. Institutional change is possible as evideneed in dramatic changes afoot across the country in serving undergraduate students. An example of some of these institutional changes are the creation of freshmen learning communities, residential programs (living and learning), improved advising and orientation programs, ethnic centers, and support groups, which have all been put in place to improve retention. While institutions have taken notice of the problem of undergraduate student departure, few institutions share that concern for doctoral students. As this study and others suggest (Abedi \& Benkin, 1987; Bowen \& Rudenstine, 1992; Golde, 2005, 1998; Gonzalez et al., 200 1, 2002; Ibarra, 1996; Lovitts, 200I; Nettles, 1990; Solorzano, 1993), doctoral student departure is a serious issue which can be diminished with appropriate measures. More attention to graduate level retention in general and to underrepresented groups in particular, will serve both the academic and public spheres.

\section{REFERENCES}

Abedi. J., \& Benkin, E. (1987). The effects of student's academic, financial and demographic variables on time to doctoratc. Research in Higher Education, 27(1), 3-14.

Bogardus, E. S. (1925). Social distance and its origins. Joumal of Applied Sociology, 1925, 216-226.

Bowen, W. G., \& Rudenstine, N. L. (1992). In pursuit of the P/.D. Princeton, NJ: Princeton University Press.

Cuadraz, G. H. (1992). Experiences of multiple marginality: A case study of Chicana "scholarship women." In C. Turner et al. (Eds.), Racial and ethnic diversity in higher education (pp. 210-222). Needham Heights, MA: Simon and Schuster Custom Publishing.

Cuadraz. G. II. (1993) Meritocracy unchallenged: The making of a Chicano and Chicana professoriate and professional class. ProQuest Dissertation and Theses, $A$ \& 1 . (AAT 9407924). 
Fcagin, J. R., \& Vera, H. (1995). White racism. New York: Routledge.

Fox. R. N. ( 1986). Application of conceptual model of college withdrawal to disadvantaged students. American Educational Research Journal. 23, 415-424.

Gandara, P. (1982). Passing through the eye of a ncedlc: High achieving Chicanas. Hispanic Journal of Behavioral Sciences, 47, 167-179.

Gandara, P. (1993). Choosing higher education; The educational mobility of Chicano students. Berkeley, CA: The Califomia Policy Seminar.

Gandara, P. (1995). Over the ivy walls: The educational mobility of low-income Chicanos. Albany: State University of New York Press.

Golde, C. M. (2005). The role of the department and discipline in doctoral student attrition: Lessons from four departments. The Journal of Iligher Echucation. 76(6), 669-700.

Golde, C. M. (1998). Beginning graduate school: Explaining first-year doctoral attrition. New Directions for Higher Education, 101, 55-64.

Gonzalez, K., Marin, P., Perez, L. X., Figueroa, M. A., Moreno, J. F., \& Navia, C. N. (2001). Understanding the nature and context of Latina/o doctoral student experiences. Journal of College Student Development, 42, 563-579.

Gonzalez, K., Marin, P., Figucroa, M. A., Moreno, J. F., \& Navia, C. N. (2002). Inside doctoral education in America: Voices of Latinas/os in pursuit of the Ph.D. Iournal of College Student Development, 43, 540-557.

Hurtado, S. (1992). Campus racial climatc: Contexts of conflict. Journal of Higher Education, 63, 539-569.

Hurtado, S., \& Carter, D. (1997). Effects of college transition and perceptions of the campus racial climate on Latino college students' sense of belonging. Sociology of Education, 70, 324-345.

Hurtado, S., Maestas, R., Hill, L., Inkelas, K. K., Wathington, H., \& Waterson, E. (1998). Perspectives on the climate for diversity: Findings and recommendations for the cumpus community. The University of Michigan: Center for the Study of Higher and Postsecondary Education.

Ibarra, R. A. (1996). Latino experiences in graduate education: Implications for changeA preliminary report. Washington, DC: Council of Graduate Schools.

Ibarra, R. A. (2001). Beyond affirmative action: Reframing the context of higher education university. Madison: University of Wisconsin Press.

Llagas, C. (2003). Status and trends in the education of Hispanics. Washington, DC: National Center for Education Statistics. Report No: NCES-2003-008.

Loeb, P. R. (1994). Gieneration at the crossroads: Apathy and action on the American campus. New Brunswick, NJ: Rutgers University Press.

Loo, C., \& Rolison, G. (1986). Alienation of ethnic minority students at a predominantly White university. Joumal of Higher Education, 57, 58-77.

Lovitts, B. E. (2001). Leaving the ivorv tower: The causes and consequences of departure from doctoral study. Maryland: Rowman and Littlefield Publishers, Inc.

National Center for Fducation Statistics [NCES]. (2003). Digest of educational statistic:s. Retrieved September 15, 2005. http:i/nces.ed.gove/programs/digest/d04/tables/dt04_228.asp

National Center for Education Statistics [NCES]. (2004). Digest of educational statistic: Table 228 Employees in degrec-granting institutions, by race/cthnicity, primary occupation, sex, employment status, and control and type of institution: Fall 
2001. Retricved July 28, 2005.

http://nces.ed.gov/programs/digest/d04/tables/dt04 228.asp

National Council of La Raza. (1998). Latino education stanus and prospects: State of Hispanic America 1998. Washington, DC: NCLR.

Nerad, M., \& Cerny. J. (1993). From facts to action: Expanding the educational role of the graduate division. In L. Baird (Ed.), Increasing graduate student retention and degree attainment (pp. 27-39). San Francisco: Jossey-Bass Publishers.

Nettles, M. T. (1990). Minority graduate education project report: Black. Hispanic, and White doctoral students, before, during and after enrolling in graduate school. Educational Testing Services.

Office of Institutional Research [OIR]. (2004). UNM fact book 2()()3-20()()4. Retrieved August 10, 2005. http://www.unm.edu/ oir/factbook/2004fo/2004 ref.htm

Pascarella, E. T., \& Terenzini, P. T. (1979). Interaction effects in Spady`s and Tinto`s conceptual models of college dropout. Sociology of Education. 52, 197-210.

Pascarella, E. T., \& Terenzini, P. T. (1980). Predicting freshmen persistence and voluntary dropout decisions from a theoretical model. Journal of Higher Education, 5/. 60-75.

Pascarclla, E. T., \& Chapman, D. W. (1983). Validation of a theoretical model of college withdrawal: Interaction effects in a multi-institutional sample. Research in Higher Education, 19, 25-48.

Secada, W. G., Chavez-Chavez, R., Garcia, E., Munoz, C., Oakes, I., Santiago-Santiago, I., \& Slavin. R. (1998). No more excuses: The final report of the Hispanic dropout project. Madison, WI: Department of Curriculum and Instruction, University of Wisconsin.

Sidel. R. (1994). Battling bias: The struggle for identity and community on college cumpuses. New York: Viking.

Solorzano, D. G. (1993). The road to the doctorate for California's Chicanas and Chicanos: A study of Ford Foundation Minority Fellows. Latina/Latino Policy Research Program, University of California. California Policy Seminar.

Stoecker, J., Pascarclla, E. T.. \& Wolfe, L. M. (1988). Persistence in higher education: A 9-year test of a theoretical model. Journal of College Student Development. 29. 196-209.

Terenzini, P. T., \& Pascarclla, E. T. (1977). Voluntary freshmen attrition and patterns of social and academic integration in a university: A test of a conceptual model. Research in Higher Education, 6, 25-43.

Terenzini, P. T., Lorang, W., \& Pascarella, E. T. (1981). Predicting freshmen persistence and voluntary dropout decision: A, replication. Research in Higher Education, 15, 109-127.

Tinto, V. (1975). Dropout from Higher Education: A theoretical synthesis of recent research. Review of Educational Research, 6.3. 603-617.

Tinto, V. (1987). Leaving college: Rethinking the causes and cures of student attrition (2nd ed,). Chicago: The University of Chicago Press.

Tinto, V. (1988). Stages of student departure: Reflections on the longitudinal character of student leaving. Journal of Higher Education. 59, 438-455.

Tinto, V. (1993). Leaving college: Rethinking the causes and cures of student attrition (2nd ed.) Chicago: The University of Chicago Press. 
Tracey, T. J., \& Sedlacek, W. E. (1987). A comparison of White and Black student academic success using noncognitive variables: A LISREL analysis. Research in Higher Education, 27, 333-348.

U.S. Census Bureau. (2006). State and county quick facts: New Mexico. Retrieved April 24. 2006. Available at: http://quickfacts.census.gov/qfd/states $/ 35000 . \mathrm{html}$ 